\title{
Effect of strontium atoms substitution on the features of two-slab structure of $\mathrm{Sr}_{1-\mathrm{x}} \mathrm{Ca}_{\mathrm{x}} \mathrm{La}_{2} \mathrm{Sc}_{2} \mathrm{O}_{7}$ scandates
}

\author{
Yuri Titov $^{\mathrm{a}^{*}}$, Nadezhda Belyavina ${ }^{\mathrm{b}}$, Mykola Slobodyanik $^{\mathrm{a}}$, Olesya Nakonechna ${ }^{\mathrm{b}}$, \\ Nataliia Strutynska ${ }^{\mathrm{a}}$ \\ ${ }^{a}$ Department of Chemistry, Taras Shevchenko National University of Kyiv, Volodymyrska Street, \\ 64/13, Kyiv 01601, Ukraine \\ ${ }^{\mathrm{b}}$ Department of Physics, Taras Shevchenko National University of Kyiv, \\ Acad. Glushkova avenue, 4-b, Kyiv 03022, Ukraine Affiliation
}

tit@univ.kiev.ua

Keywords: Ruddlesden-Popper compound, solid solution, X-ray powder diffraction method, slab perovskite-like structure.

Effects of substitution of the Strontium atoms with smaller Calcium atoms on the structural features of the Ruddlesden-Popper $\mathrm{SrLa}_{2} \mathrm{Sc}_{2} \mathrm{O}_{7}$ two-slab compound is established. The crystal structure of orthorhombic $\mathrm{Sr}_{0.85} \mathrm{Ca}_{0.15} \mathrm{La}_{2} \mathrm{Sc}_{2} \mathrm{O}_{7}$ phase with maximum degree of substitution was determined by the Rietveld method (Fmmm space group, $a=0.5766(2) \mathrm{nm}, b=0.5743(2) \mathrm{nm}, c=2.0522(7) \mathrm{nm}$ ). Comparison of the structural features of $\mathrm{SrLa}_{2} \mathrm{Sc}_{2} \mathrm{O}_{7}$ and $\mathrm{Sr}_{0.85} \mathrm{Ca}_{0.15} \mathrm{La}_{2} \mathrm{Sc}_{2} \mathrm{O}_{7}$ shows that such type of substitution leads to a decrease in the (La,Sr)2 - O2 interblock bond length (from 0.222 (2) nm at $\mathrm{x}=0$ to $0.215(1) \mathrm{nm}$ at $\mathrm{x}=0.15)$. The decrease in interblock bond length brings the constitution of the two-dimensional structure $\mathrm{Sr}_{1-\mathrm{x}} \mathrm{Ca}_{\mathrm{x}} \mathrm{La}_{2} \mathrm{Sc}_{2} \mathrm{O}_{7}$ closer to the structure of the three-dimensional perovskite, leads to its instability at $\mathrm{x}>0.15$ and gives a reason to conclude that this factor causes a limitation of region of the $\mathrm{Sr}_{1-\mathrm{x}} \mathrm{Ca}_{\mathrm{x}} \mathrm{La}_{2} \mathrm{Sc}_{2} \mathrm{O}_{7}$ solid solutions with a slab perovskite-like structure. Presence of such structure changes is the precondition for regulation of structural-dependent features of the materials on the base of scandates alkaline-earth and rare earth metals.

\section{Introduction}

Family representatives of the Ruddlesden-Popper $\quad \mathrm{A}_{\mathrm{n}+1} \mathrm{~B}_{\mathrm{n}} \mathrm{O}_{3 \mathrm{n}+1} \quad$ compounds with slab perovskite-like structure (SPS) are characterized by a complex of valuable functional properties such as ionic conductivity, significant magnetoresistance, photocatalytic activity as well as dielectric, resistive, ion- exchange and luminescent properties [1-8]. It is known that one of the ways to effect the structure and, consequently, structurally dependent properties of oxide materials is an isomorphic substitution of atoms. Recently, the effect of isovalent substitutions of the A- / Batomic positions on the structure of SPS phases were studied for several two-slab $(n=2)$ 
$\mathrm{A}^{\mathrm{II}} \mathrm{Ln}_{n} \mathrm{~B}_{\mathrm{n}} \mathrm{O}_{3 n+1} \quad$ compounds (phases of mode under the following scanning parameters: $\mathrm{SrLa}_{2-\mathrm{x}} \mathrm{Dy}_{\mathrm{x}} \mathrm{Sc}_{2} \mathrm{O}_{7}$ [9], $\mathrm{Ba}_{1-\mathrm{x}} \mathrm{Sr}_{\mathrm{x}} \mathrm{La}_{2} \mathrm{In}_{2} \mathrm{O}_{7}$ [10], observation range $2 \theta=(20-75)^{\circ}$, step scan of $\mathrm{SrLa}_{2} \mathrm{Sc}_{2-\mathrm{x}} \mathrm{In}_{\mathrm{x}} \mathrm{O}_{7}$ [11] and $\mathrm{BaLa}_{2-\mathrm{x}} \mathrm{Sm}_{\mathrm{x}} \mathrm{In}_{2} \mathrm{O}_{7}$ [12] $0.02^{\circ}$ and counting time per step at $5 \mathrm{~s}$. The type). However, both the possibility of calcium atoms embedding in the two-slab SPS of $\mathrm{A}^{\mathrm{II}} \mathrm{Ln}_{n} \mathrm{~B}_{\mathrm{n}} \mathrm{O}_{3 \mathrm{n}+1}$ compounds and nature of this type of substitution on the structure of Ca-containing $\mathrm{A}^{\mathrm{II}} \mathrm{Ln}_{n} \mathrm{~B}_{\mathrm{n}} \mathrm{O}_{3 \mathrm{n}+1}$ compounds have not been studied yet.

The purpose of this work is to study the conditions and effect of substitution of strontium by calcium on the features of SPS phases of $\mathrm{Sr}_{1-\mathrm{x}} \mathrm{Ca}_{\mathrm{x}} \mathrm{La}_{2} \mathrm{Sc}_{2} \mathrm{O}_{7}$ - type.

\section{Experimental part}

$\mathrm{Sr}\left(\mathrm{NO}_{3}\right)_{2}, \quad \mathrm{Ca}\left(\mathrm{NO}_{3}\right)_{2}, \quad \mathrm{La}\left(\mathrm{NO}_{3}\right)_{3}$, $\mathrm{Sc}\left(\mathrm{NO}_{3}\right)_{3}$ (chemistry pure reagents) were used as the source materials. Synthesis of the $\mathrm{Sr}_{1-\mathrm{x}} \mathrm{Ca}_{\mathrm{x}} \mathrm{La}_{2} \mathrm{Sc}_{2} \mathrm{O}_{7}$ polycrystalline scandates was carried out by co-crystallization (evaporation $(\sim 350-360 \mathrm{~K})$ at intensive mixing) of the mixture of aqueous solutions of strontium, calcium, lanthanum and scandium nitrates (ratio is equal to $\mathrm{Sr}: \mathrm{Ca}: \mathrm{La}: \mathrm{Sc}=1-\mathrm{x}: \mathrm{x}: 2: 2$ ) with further thermal treatment of the product obtained on air- methane burner to remove the main part of the nitrogen oxides. Then the powder obtained was ground, pressed as tablets and heat treated at $1570 \mathrm{~K}$ to achieve the constant phase composition.

X-ray diffraction data was collected with a Shimadzu XRD-6000 automatic diffractometers $\left(\mathrm{Cu} K_{\alpha}\right.$ radiation $(\lambda=0,154178$ $\mathrm{nm})$, graphite monochromator) in a discrete original software package [13], including full complex of standard Rietveld procedures, has been used for analysis and interpretation of the $\mathrm{X}$-ray diffraction patterns obtained, namely, for determination of both peak positions and integral intensities of the Bragg's reflections by means of full profile analysis; carrying out phase analysis for phase identification and the least square method for lattice parameters refinement; testing of the structure models and refining crystal structure parameters (including coordinates of the atoms, atomic position filling, texture, etc.).

Tests for generation of the second $I_{2 \omega}$ were performed on polycrystalline samples using the Nd:YAG laser $\left(\lambda_{\omega}=1.064 \mu \mathrm{m}\right.$ and $\left.\lambda_{2 \omega}=0.532 \mu \mathrm{m}\right)$. The powder of four-slab $\mathrm{La}_{4} \mathrm{Ti}_{4} \mathrm{O}_{14}$ ferroelectric was used as a standard material for estimating the non-centrosymmetric structure.

\section{Results and discussion}

The results of X-ray diffraction study of the samples obtained from the heat treated co-crystallized $\mathrm{Sr}, \mathrm{Ca}, \mathrm{La}$ and $\mathrm{Sc}$ nitrates has revealed the existence of a narrow $(0 \leq \mathrm{x} \leq 0.15)$ single-phase region of $\mathrm{Sr}_{1-\mathrm{x}} \mathrm{Ca}_{\mathrm{x}} \mathrm{La}_{2} \mathrm{Sc}_{2} \mathrm{O}_{7}$ phases with two-slab SPS. Further increase of Ca content $(\mathrm{x}=0.2,0.25$, $0.3,0.35)$ leads to formation of two-slab phase and the three dimensional perovskite phase with 
increasing calcium content. Besides, the $\mathrm{LaScO}_{3}$-based phase with the structure of orthorhombic perovskite is dominant (content $>$ $90 \%$ ) in the non-single-phase sample of $\mathrm{CaLa}_{2} \mathrm{Sc}_{2} \mathrm{O}_{7}$ bulk composition.

The diffraction patterns of the $\mathrm{Sr}_{1-\mathrm{x}} \mathrm{Ca}_{x} \mathrm{La}_{2} \mathrm{Sc}_{2} \mathrm{O}_{7}$ phases with SPS were shown to be similar to the diffraction pattern of $\mathrm{SrLa}_{2} \mathrm{Sc}_{2} \mathrm{O}_{7}$ individual compound (sp. gr. Fmmm [14]) and indexing well in the orthorhombic cell with reflections, limiting by such conditions: $h k l$ with $h+k=2 \mathrm{n}, k+l=2 \mathrm{n}$, $h+l=2 \mathrm{n}, 0 k l$ with $k, l=2 \mathrm{n}, h 0 l$ with $h, l=2 \mathrm{n}$, $h k 0$ with $h, k=2 \mathrm{n}, h 00,0 k 0,00 l$ with $h, k, l=$ 2n. Thus, available systematic extinctions could correspond to the following space groups: centrosymmetric Fmmm and noncentrosymmetric Fmm2, F222. Comparison of the second optical harmonic signals of the $\mathrm{Nd}$ : YAG laser radiation for the studied $\mathrm{Sr}_{1-\mathrm{x}} \mathrm{Ca}_{\mathrm{x}} \mathrm{La}_{2} \mathrm{Sc}_{2} \mathrm{O}_{7}$ phases with SPS and for the centrosymmetric $\mathrm{SrLa}_{2} \mathrm{Sc}_{2} \mathrm{O}_{7}$ compound showed that their $\mathrm{I} 2_{\omega}$ intensities are close to each other, which indicates that the crystal structure of the $\mathrm{Sr}_{1-\mathrm{x}} \mathrm{Ca}_{\mathrm{x}} \mathrm{La}_{2} \mathrm{Sc}_{2} \mathrm{O}_{7}$ phases studied belongs to the centrosymmetric Fmmm space group.

Based on the results obtained we have determined the SPS for $\mathrm{Sr}_{0.85} \mathrm{Ca}_{0.15} \mathrm{La}_{2} \mathrm{Sc}_{2} \mathrm{O}_{7}$ phase with maximum substitution degree of $\mathrm{Sr}$ atoms (x) equal to 0.15 .

Considering the similarity of the $\mathrm{Sr}_{0.85} \mathrm{Ca}_{0.15} \mathrm{La}_{2} \mathrm{Sc}_{2} \mathrm{O}_{7}$ and the $\mathrm{SrLa}_{2} \mathrm{Sc}_{2} \mathrm{O}_{7}$ diffraction patterns, the atomic coordinates in
$\mathrm{SrLa}_{2} \mathrm{Sc}_{2} \mathrm{O}_{7}$ (sp. gr. Fmmm) [14] were uses for the construction of initial model of $\mathrm{Sr}_{0.85} \mathrm{Ca}_{0.15} \mathrm{La}_{2} \mathrm{Sc}_{2} \mathrm{O}_{7}$ structure.

This structural model demonstrates a good agreement of the observed and calculated intensities. The results of the refinement procedure and diffraction data are summarized in Tables 1, 2, and are shown in Figures 1 - 3. The calculated composition of $\mathrm{Sr}_{0.85} \mathrm{Ca}_{0.15} \mathrm{La}_{2} \mathrm{Sc}_{2} \mathrm{O}_{7}$ phase obtained by refinement procedure corresponds to the experimentally specified one within the accuracy of calculation.

It's worthy to note that two-dimensional (infinite in the $a b$ plane) perovskite-like blocks form the basis of SPS $\mathrm{Sr}_{0.85} \mathrm{Ca}_{0.15} \mathrm{La}_{2} \mathrm{Sc}_{2} \mathrm{O}_{7}$. Each of these blocks consists of two slabs of deformed $\mathrm{ScO}_{6}$ octahedra (Figure 2) connected by the vertices in a way that each octahedron has five common vertices with adjacent octahedra of the same block. Adjacent blocks are shifted by half of $\mathrm{ScO}_{6}$ octahedron height in direction of the diagonal of $a b$ plane and are subsequently alternated along [001] (Figure 2)

By varying and refining of possible variants of the $\mathrm{Sr}, \mathrm{Ca}, \mathrm{La}$ atoms arrangement in the phase studied, it was shown that the calcium atoms in SPS of $\mathrm{Sr}_{0.85} \mathrm{Ca}_{0.15} \mathrm{La}_{2} \mathrm{Sc}_{2} \mathrm{O}_{7}$ phase are located only in the intrablock voids of the perovskite-like block (Table 1, position 4b), while the strontium and lanthanum atoms are statistically distributed both in $4 \mathrm{~b}$ and $8 \mathrm{i}$ positions with predominant localization of 


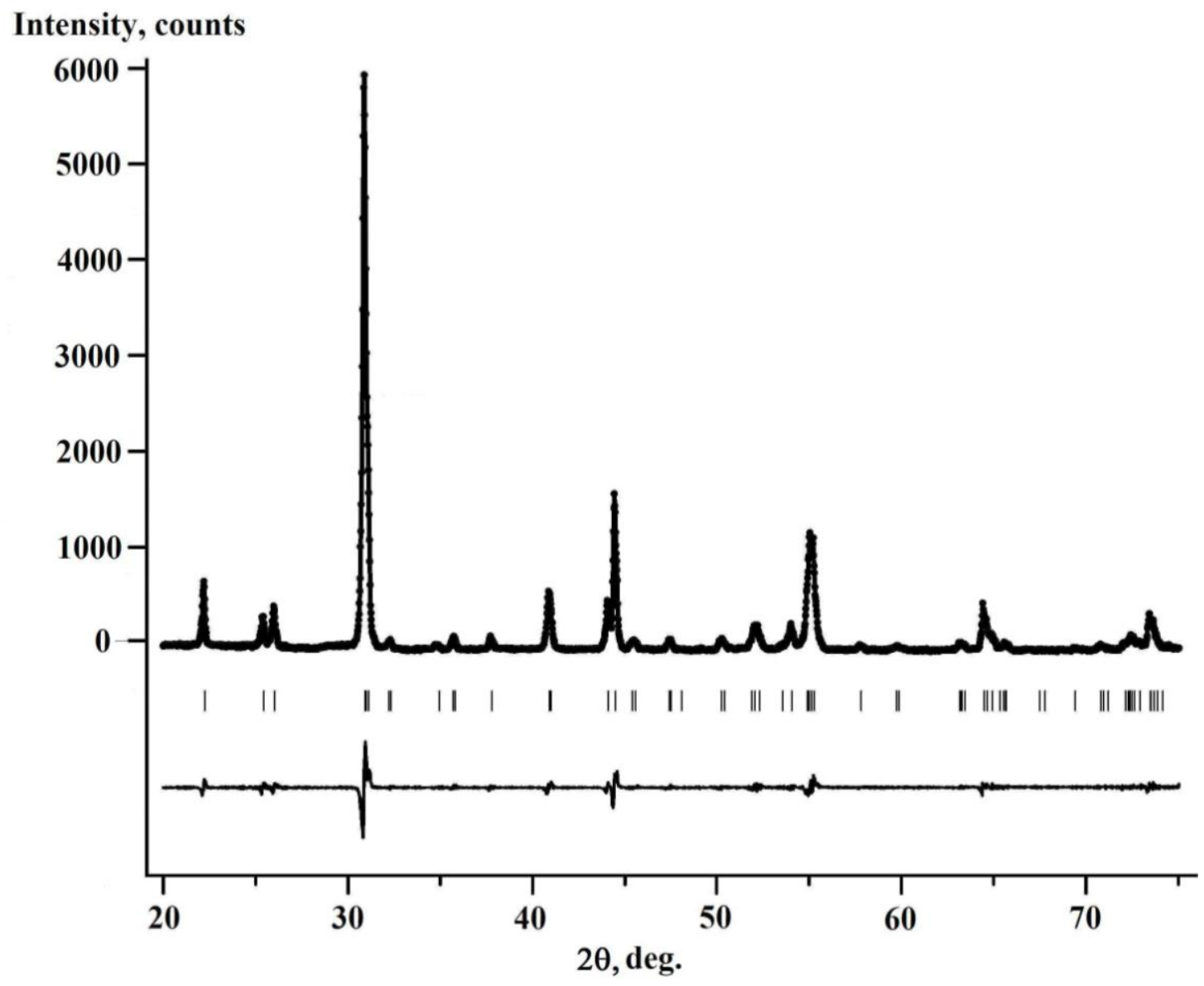

Figure 1. Diffraction pattern (points), calculated pattern (solid line) and difference curve for $\mathrm{Sr}_{0.85} \mathrm{Ca}_{0.15} \mathrm{La}_{2} \mathrm{Sc}_{2} \mathrm{O}_{7}$ (sp. gr. Fmmm) $\left(\mathrm{Cu} K_{\alpha}\right.$ radiation)

lanthanum atoms at the boundaries of the perovskite-like block (Table 1, position 8i). Such distribution of strontium and lanthanum atoms is similar to that in unsubstituted $\mathrm{SrLa}_{2} \mathrm{Sc}_{2} \mathrm{O}_{7}$ scandate structure.

There is no direct connection between $\mathrm{ScO}_{6}$ octahedra, which are placed in neighbourig perovskite-like blocks of $\mathrm{Sr}_{0.85} \mathrm{Ca}_{0.15} \mathrm{La}_{2} \mathrm{Sc}_{2} \mathrm{O}_{7}$ SPS. Adjacent blocks are separated by a slab of $(\mathrm{La}, \mathrm{Sr}) 2 \mathrm{O}_{9}$ polyhedra and are held together by means of - O - (La,Sr)2 - O - interblock bonds (Figure 3).

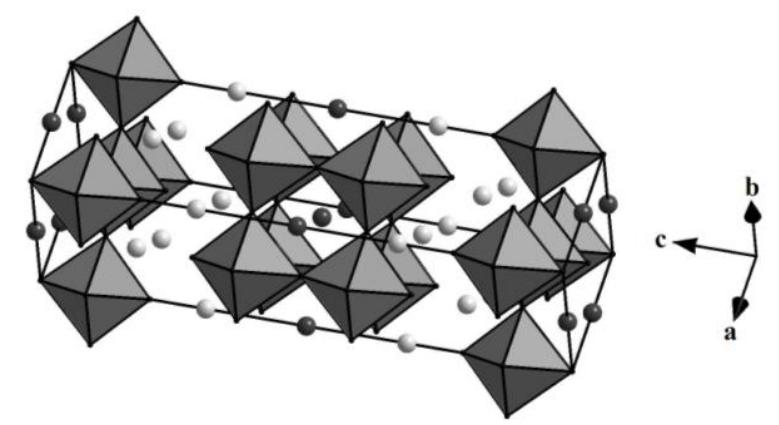

Figure 2. Crystal structure of the $\mathrm{Sr}_{0.85} \mathrm{Ca}_{0.15} \mathrm{La}_{2} \mathrm{Sc}_{2} \mathrm{O}_{7}$ phase as an arrangement of the $\mathrm{ScO}_{6}$ octahedra, $\mathrm{Sr}, \mathrm{La}$ atoms (light circles) and $\mathrm{Sr}, \mathrm{Ca}, \mathrm{La}$ atoms (dark circles).

Eight of the nine oxygen atoms of the ( $\mathrm{La}, \mathrm{Sr}) 2 \mathrm{O}_{9}$ polyhedron, namely, four $\mathrm{O} 2$ and four $\mathrm{O} 3$ atoms, belong to the same slab as $(\mathrm{La}, \mathrm{Sr}) 2$ atoms, while one oxygen atom $(\mathrm{O} 2)$ belongs to the neighboring block (Figure 3). 

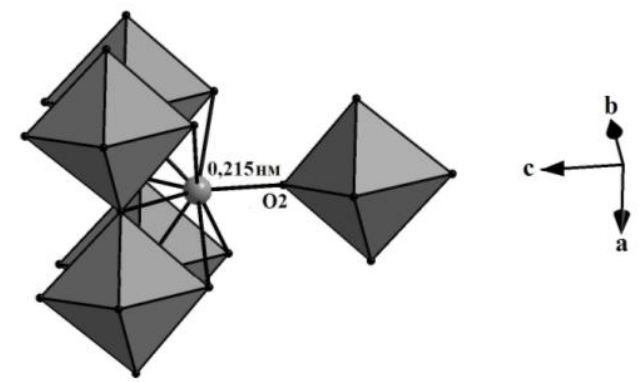

Figure 3. Structure of interblock boundary of the $\mathrm{Sr}_{0.85} \mathrm{Ca}_{0.15} \mathrm{La}_{2} \mathrm{Sc}_{2} \mathrm{O}_{7}$ SPS in the form of $\mathrm{ScO}_{6}$ octahedra and ( $\mathrm{La}, \mathrm{Sr}) 2$ atoms (grey circle).

The length of this interblock bond (0.215 (1) $\mathrm{nm})$ is the smallest in the $(\mathrm{La}, \mathrm{Sr}) 2 \mathrm{O}_{9}$ polyhedron and less than the interblock bond $(\mathrm{La}, \mathrm{Sr}) 2-\mathrm{O} 2$ in $\mathrm{SrLa}_{2} \mathrm{Sc}_{2} \mathrm{O}_{7}$ (Table 2).

Table 1. Crystal data for $\mathrm{Sr}_{0.85} \mathrm{Ca}_{0.15} \mathrm{La}_{2} \mathrm{Sc}_{2} \mathrm{O}_{7}$ phase.

\begin{tabular}{|c|c|c|c|c|c|}
\hline Site & Atom & $\begin{array}{l}\text { Occu- } \\
\text { pation }\end{array}$ & $x$ & $y$ & $z$ \\
\hline \multirow{3}{*}{$4 b$} & Sr1 & $0.44(2)$ & \multirow{3}{*}{0} & \multirow{3}{*}{0} & \multirow{3}{*}{0.5} \\
\hline & La1 & $0.41(2)$ & & & \\
\hline & $\mathrm{Ca} 1$ & $0.15(2)$ & & & \\
\hline \multirow{2}{*}{$8 i$} & $\mathrm{Sr} 2$ & $0.21(2)$ & \multirow{2}{*}{0} & \multirow{2}{*}{0} & \multirow{2}{*}{$0.3107(2)$} \\
\hline & La2 & $0.79(2)$ & & & \\
\hline $8 i$ & $\mathrm{Sc}$ & 1 & 0 & 0 & $0.1004(3)$ \\
\hline $4 a$ & $\mathrm{O} 1$ & 1 & 0 & 0 & 0 \\
\hline $8 i$ & $\mathrm{O} 2$ & 1 & 0 & 0 & $0.206(2)$ \\
\hline $16 j$ & $\mathrm{O} 3$ & 1 & 0.25 & 0.25 & $0.108(2)$ \\
\hline \multicolumn{2}{|c|}{ Space group } & \multicolumn{4}{|c|}{ Fmmm (no 69) } \\
\hline \multicolumn{2}{|c|}{ Lattice parameters, $\mathrm{nm}$} & & $\begin{array}{l}a=0 . \\
b=0 . \\
c=2 .\end{array}$ & $\begin{array}{l}5766(2 \\
5743(2 \\
0522(7\end{array}$ & \\
\hline \multicolumn{2}{|c|}{ Independent reflections } & \multicolumn{4}{|c|}{62} \\
\hline \multicolumn{2}{|c|}{$\begin{array}{c}\text { Total isotropic factor, } \\
\mathrm{nm}^{2}\end{array}$} & \multicolumn{4}{|c|}{$\begin{array}{c}B_{\mathrm{Sr}, \mathrm{La}, \mathrm{Ca}, \mathrm{Sc}}=1.08(4) \cdot 10^{-2} \\
B_{\mathrm{O}}=2.93(5) \cdot 10^{-2}\end{array}$} \\
\hline \multicolumn{2}{|c|}{ Reliability factors } & \\
\hline \multicolumn{2}{|c|}{$R_{I}$} & \multicolumn{4}{|c|}{0.049} \\
\hline \multicolumn{2}{|c|}{$R$ wp } & \multicolumn{4}{|c|}{0.084} \\
\hline \multicolumn{2}{|c|}{$\mathrm{R}_{0}$} & \multicolumn{4}{|c|}{0.031} \\
\hline
\end{tabular}

Table 2. Selected interatomic distances $(d)$ and degree of distortion $(\Delta)$ of $\mathrm{MeO}_{\mathrm{n}}$ polyhedra in the crystal structure of $\mathrm{SrLa}_{2} \mathrm{Sc}_{2} \mathrm{O}_{7}$ and $\mathrm{Sr}_{0.85} \mathrm{Ca}_{0.15} \mathrm{La}_{2} \mathrm{Sc}_{2} \mathrm{O}_{7}$

\begin{tabular}{|c|c|c|c|}
\hline \multicolumn{2}{|c|}{$\mathrm{SrLa}_{2} \mathrm{Sc}_{2} \mathrm{O}_{7}[14]$} & \multicolumn{2}{|c|}{$\mathrm{Sr}_{0.85} \mathrm{Ca}_{0.15} \mathrm{La}_{2} \mathrm{Sc}_{2} \mathrm{O}_{7}$} \\
\hline $\begin{array}{l}\text { Atom }- \text { atom } \\
\text { and } \Delta^{1)}\end{array}$ & $d, \mathrm{~nm}$ & $\begin{array}{l}\text { Atom }- \text { atom } \\
\text { and } \Delta^{1)}\end{array}$ & $d, \mathrm{~nm}$ \\
\hline$(\mathrm{Sr}, \mathrm{La}) 1-2 \mathrm{O} 1$ & $0.287(3)$ & $(\mathrm{Sr}, \mathrm{La}, \mathrm{Ca}) 1-2 \mathrm{O} 1$ & $0.287(2)$ \\
\hline$-2 \mathrm{O} 1$ & $0.288(3)$ & $-2 \mathrm{O} 1$ & $0.288(3)$ \\
\hline$-8 \mathrm{O} 3$ & $0.299(2)$ & $-8 \mathrm{O} 3$ & $0.301(2)$ \\
\hline$((\mathrm{Sr}, \mathrm{La}) 1-\mathrm{O})_{\text {aver. }}$ & 0.295 & $((\mathrm{Sr}, \mathrm{La}, \mathrm{Ca}) 1-\mathrm{O})_{\text {aver }}$ & 0.296 \\
\hline$\Delta(\mathrm{Sr}, \mathrm{La}) 1 \mathrm{O}_{12}$ & $3 \cdot 10^{-4}$ & $\Delta(\mathrm{Sr}, \mathrm{La}, \mathrm{Ca}) 1 \mathrm{O}_{12}$ & $5 \cdot 10^{-4}$ \\
\hline$(\mathrm{La}, \mathrm{Sr}) 2-\mathrm{O} 2)^{2)}$ & $0.222(2)$ & $(\mathrm{La}, \mathrm{Sr}) 2-\mathrm{O} 2)^{2)}$ & $0.215(1)$ \\
\hline$-4 \mathrm{O} 3$ & $0.260(2)$ & $-4 \mathrm{O} 3$ & $0.263(2)$ \\
\hline$-2 \mathrm{O} 2$ & $0.290(1)$ & $-2 \mathrm{O} 2$ & $0.289(2)$ \\
\hline$-2 \mathrm{O} 2$ & $0,292(1)$ & $-2 \mathrm{O} 2$ & $0.290(2)$ \\
\hline$((\mathrm{La}, \mathrm{Sr}) 2-\mathrm{O})_{\text {aver. }}$ & 0.270 & $((\mathrm{La}, \mathrm{Sr}) 2-\mathrm{O})_{\text {aver. }}$ & 0.269 \\
\hline$\Delta(\mathrm{La}, \mathrm{Sr}) 2 \mathrm{O}_{9}$ & $68 \cdot 10^{-4}$ & $\Delta(\mathrm{La}, \mathrm{Sr}) 2 \mathrm{O}_{9}$ & $72 \cdot 10^{-4}$ \\
\hline $\mathrm{Sc}-4 \mathrm{O} 3$ & $0.204(1)$ & $\mathrm{Sc}-4 \mathrm{O} 3$ & $0.204(2)$ \\
\hline$-\mathrm{O} 1$ & $0.206(2)$ & $-\mathrm{O} 1$ & $0.206(1)$ \\
\hline$-\mathrm{O} 2$ & $0.217(3)$ & $-\mathrm{O} 2$ & $0.217(2)$ \\
\hline$(\mathrm{Sc}-\mathrm{O})_{\text {aver. }}$ & 0.207 & $(\mathrm{Sc}-\mathrm{O})_{\text {aver. }}$ & 0.207 \\
\hline$\Delta \mathrm{ScO}_{6}$ & 5. $10^{-4}$ & $\Delta \mathrm{ScO}_{6}$ & $5 \cdot 10^{-4}$ \\
\hline
\end{tabular}

${ }^{1}$ The degrees of distortion of the $M e \mathrm{O}_{n}$ polyhedra were calculated as $\Delta=1 / n \sum\left[\left(R_{i}-\bar{R}\right) / \bar{R}\right]^{2}$ (where $R_{i}$ is the $M e-\mathrm{O}$ distance, $\bar{R}$ is the $M e-\mathrm{O}$ average distance, $n$ is the coordination number for $M e$ ) [12]

${ }^{2}$ Interblock distance $(\mathrm{O}(2)$ atom located in the neighbour perovskite-like block).

Four $\mathrm{O} 2$ atoms in the $(\mathrm{La}, \mathrm{Sr}) 2 \mathrm{O}_{9}$ polyhedron are located at much longer distances (0.289 (2) - 0.290 (2) nm (Table 2) from the atom of the (La,Sr)2 type. Therefore, the coordination number of central atoms in the $(\mathrm{La}, \mathrm{Sr}) 2 \mathrm{O}_{9}$ polyhedron could be assumed as $1+4+4$ (considering the presence of the shortest (La,Sr)2 - O2 interblock bond. The coordination number of $(\mathrm{Sr}, \mathrm{La}, \mathrm{Ca}) 1$ intrablock 
atoms is equal to 12 , their coordination polyhedron is a deformed cuboctahedron $(\mathrm{Sr}, \mathrm{La}, \mathrm{Ca}) 1 \mathrm{O}_{12}$.

Comparison of the data on the structure of the $\mathrm{Sr}_{0.85} \mathrm{Ca}_{0.15} \mathrm{La}_{2} \mathrm{Sc}_{2} \mathrm{O}_{7}$ phase obtained in this work with the structure of the $\mathrm{SrLa}_{2} \mathrm{Sc}_{2} \mathrm{O}_{7}$ unsubstituted scandate [14] showed that the embedding of smaller calcium atoms into the A-position of SPS leads to a shortening of the distance between the two-slab perovskite-like slabs. Further approach of the two-slab blocks of $\mathrm{ScO}_{6}$ octahedra results in the transformation of $\mathrm{Sr}_{1-\mathrm{x}} \mathrm{Ca}_{\mathrm{x}} \mathrm{La}_{2} \mathrm{Sc}_{2} \mathrm{O}_{7}$ SPS at $\mathrm{x}>0.15$ caused by the joining of $\mathrm{ScO}_{6}$ octahedra of neighboring blocks. In this case, a three-dimensional perovskite network based on orthorhombic $\mathrm{LaScO}_{3}$ is formed instead of two-dimensional blocks of two slabs of $\mathrm{ScO}_{6}$ octahedra, As a result, the interblock $(\mathrm{La}, \mathrm{Sr}) \mathrm{O}_{9}$ polyhedra are transformed into the $(\mathrm{La}, \mathrm{Sr}) \mathrm{O}_{12}$ cuboctahedron of the perovskite structure and the intrablock $(\mathrm{Sr}, \mathrm{Ca}, \mathrm{La}) \mathrm{O}_{12}$ polyhedra remain unchanged in the closed cuboctahedron voids formed by the $\mathrm{ScO}_{6}$ octahedron connected by vertices.

The identified features of the SPS of the $\mathrm{Sr}_{0.85} \mathrm{Ca}_{0.15} \mathrm{La}_{2} \mathrm{Sc}_{2} \mathrm{O}_{7}$ phase lead us to conclude that it is the size factor that determine the narrow range of $\mathrm{Sr}_{1-\mathrm{x}} \mathrm{Ca}_{\mathrm{x}} \mathrm{La}_{2} \mathrm{Sc}_{2} \mathrm{O}_{7}$ solid solutions with SPS as well as the impossibility of formation of the $\mathrm{CaLa}_{2} \mathrm{Sc}_{2} \mathrm{O}_{7}$ scandate with SPS.

\section{Conclusions}

In this work the conditions of isovalent substitution of strontium atoms by calcium atoms in a two-slab SPS of the $\mathrm{SrLa}_{2} \mathrm{Sc}_{2} \mathrm{O}_{7}$ scandate were revealed and the SPS of phase of $\mathrm{Sr}_{0.85} \mathrm{Ca}_{0.15} \mathrm{La}_{2} \mathrm{Sc}_{2} \mathrm{O}_{7}$ limiting composition is determined by the Rietveld method. Analysis of the data obtained made it possible to reveal the nature of the calcium atoms effect on the structure of the $\mathrm{Sr}_{1-\mathrm{x}} \mathrm{Ca}_{\mathrm{x}} \mathrm{La}_{2} \mathrm{Sc}_{2} \mathrm{O}_{7}$ scandates. The results obtained here could be used to adjust the structure-dependent properties of materials based on the $\mathrm{SrLa}_{2} \mathrm{Sc}_{2} \mathrm{O}_{7}$ scandate.

\section{References}

[1] Alexandrov KS, Beznosikov BV. Perovskity. Nastoyashcheye i budushcheye. Novosibirsk: SO RAN Publishers; 2004.

[2] Schaak RE, Mallouk TE. Perovskites by design: a toolbox of solid-state reactions. Chem. Mater. 2002;14(4):1455-1471.

[3] Kim IS, Nakamura T, Itoh M. Humidity sensing effects of the layered oxides $\mathrm{SrO} \cdot\left(\mathrm{LaScO}_{3}\right)_{\mathrm{n}}(\mathrm{n}=1,2, \infty)$. J. Ceram. Soc. Jap. 1993;101(7):800-803.

[4] Kato S, Ogasawara M, Sugai M, Nakata S. Synthesis and oxide ion conductivity of new layered perovskite $\mathrm{La}_{1-\mathrm{x}} \mathrm{Sr}_{1+\mathrm{x}} \mathrm{InO}_{4-\mathrm{d}}$. Solid state ionics. 2002;149(1-2):53-57.

[5] Lobanov MV, Greenblatt M, Caspi EN, Jorgensen JD, Sheptyakov DV, Toby BH, Botez CE, Stephens PW. Crystal and magnetic structure of the $\mathrm{Ca}_{3} \mathrm{Mn}_{2} \mathrm{O}_{7}$ Ruddlesden-Popper phase: neutron and synchrotron x-ray diffraction study. J. Phys.: Condens. Matter. 2004;16(29):53395348.

[6] Shimizu K, Itoh S, Hatamachi T, Kodama T, Sato M, Toda K. Photocatalytic water splitting on Niintercalated Ruddlesden-Popper tantalate $\mathrm{H}_{2} \mathrm{La}_{2 / 3} \mathrm{Ta}_{2} \mathrm{O}_{7}$. Chem. Mater. 2005;17(20):5161-5166.

[7] Titov Y, Nedilko SG, Chornii V, Scherbatskii V, Belyavina N, Markiv V, Polubinskii V. Crystal structure and luminescence of layered perovskites $\mathrm{Sr}_{3} \mathrm{LnInSnO}_{8}$. Solid State Phenomena. 2015;230:67-72. 
[8] Yang HM, Shi JX, Gong ML. A new luminescent material, $\mathrm{Sr}_{2} \mathrm{SnO}_{4}: \mathrm{Eu}^{3+}$. J. Alloys and Compounds. 2006;415(1-2)213-215.

[9] Titov YO, Belyavina NM, Slobodyanik MS, Chumak VV, Nakonechna OI. Syntez ta krystalichna struktura izovalentnozamishchenykh sharuvatykh skandativ $\mathrm{SrLa}_{2}$ ${ }_{x} \mathrm{Dy}_{\mathrm{x}} \mathrm{Sc}_{2} \mathrm{O}_{7}$. Voprosy Khimii i Khimicheskoi Tekhnologii. 2019;6:228-235.

[10] Titov YO, Belyavina NM, Slobodyanik MS, Chumak VV. Krystalichna struktura izovalentnozamishchenykh sharuvatykh indativ $\mathrm{Ba}_{1-\mathrm{x}} \mathrm{Sr}_{\mathrm{x}} \mathrm{La}_{2} \operatorname{In}_{2} \mathrm{O}_{7}$. Dopovidi Natsionalnoi Akademii Nauk Ukrainy. 2016;6:95-102.

[11] Titov YO, Belyavina NM, Slobodyanik MS, Chumak VV, Nakonechna OI. Osoblyvosti budovy dvosharovoi struktury $\quad \mathrm{SrLa}_{2} \mathrm{Sc}_{2-\mathrm{x}} \mathrm{In}_{\mathrm{x}} \mathrm{O}_{7}$. Voprosy Khimii i Khimicheskoi Tekhnologii. 2020;2:118-124.

[12] Titov Y, Belyavina N, Slobodyanik M, Nakonechna O, Strutynska N, Tymoshenko M. Effect of isovalent substitution on the crystal structure and properties of two-slab indates $\mathrm{BaLa}_{2-\mathrm{x}} \mathrm{Sm}_{\mathrm{x}} \mathrm{In}_{2} \mathrm{O}_{7}$. Open Chemistry. 2020;18(1):1294-1303.

[13] Dashevskyi M, Boshko O, Nakonechna O, Belyavina N. Phase transformations at mechanical milling of the equiatomic $\mathrm{Y}-\mathrm{Cu}$ powder mixture. Metallofizika i Noveishie Tekhnologii. 2017;39(4):541-552.

[14] Titov YO, Belyavina NM, Markiv VYa, Slobodyanik MS, Krayevska YaA, Chumak VV. Syntez ta krystalichna struktura sharuvatykh skandativ $\operatorname{SrLn}_{2} \mathrm{Sc}_{2} \mathrm{O}_{7}$. Dopovidi Natsionalnoi Akademii Nauk Ukrainy. 2009;3:155161.

[15] Shannon RD. Revised effective ionic radii and systematic studies of interatomic distances in halides and halcogenides. Acta Crystallogr. 1976;A32(5):751-767. 